\title{
ASPEK KOGNITIF PENYANDANG DISABILITAS
}

\author{
Oleh: Dwi Sari Usop ${ }^{*}$, Suniati $^{* *}$, Dina Fariza Tryani Syarif ${ }^{* * *}$
}

\begin{abstract}
All children can think. However, some of them have difficulties in optimizing their thinking functions on account of their level of intelligence is below of average. This study aims to describe the cognitive aspects possessed by children with intellectual barriers. It was a qualitative method, and the subjects were 3 (three) people who belong to the second grade of elementary school.

Results of this study show deficiencies in the ability to remember lessons at school. The level of below average intelligence is one of the causes the teachings given by the teacher is equivalent to lessons for first grade students in elementary school. Even the equivalent of students in kindergarten. However, subjects can carry out other activities.
\end{abstract}

Keywords: Cognitive aspects, Students

\begin{abstract}
ABSTRAK
Semua anak mampu berpikir. Namun, beberapa diantaranya mengalami kesulitan di dalam mengoptimalkan fungsi berpikirnya dikarenakan taraf kecerdasan yang berada di bawah normal. Penelitian ini bertujuan untuk mendeskripsikan aspek kognitif yang dimiliki oleh anak dengan hambatan inteligensi. Penelitian dilaksanakan dengan metode kualitatif. Subyek penelitian berjumlah 3 (tiga) orang yang masih duduk di bangku kelas 2 sekolah dasar.

Hasil penelitian menunjukkan kekurangan di dalam kemampuan mengingat pelajaran di sekolah. Taraf kecerdasan di bawah normal menjadi salah satu penyebab sehingga pelajaran yang diberikan guru setara dengan pelajaran untuk peserta didik kelas satu sekolah dasar. Bahkan setara peserta didik pada taman kanak-kanak. Walaupun demikian, subyek dapat melakukan kegiatan-kegiatan lainnya.
\end{abstract}

Kata Kunci : Aspek kognitif, Peserta didik

\section{Pendahuluan}

Manusia, sebagai makhluk yang paling sempurna diciptakan dengan memiliki akal. Melalui akal tersebut, manusia dapat membedakan hal yang benar-salah, baik-buruk, bagus-tidak bagus. Manusia dapat merasakan dan bertindak sesuai dengan perasaan maupun pikirannya. Namun, pikiran, perasaan, maupun tindakan tersebut dinilai baik dan benar atau salah sangat erat hubungannya dengan pertumbuhan dan perkembangan manusia itu sendiri.

Di dalam diri manusia, terdapat 3 (tiga) aspek yang saling berhubungan dan mempengaruhi antara satu dengan lainnya. Ketiga aspek tersebut ialah aspek kognitif, afektif, dan psikomotorik yang mana ketiga hal ini menjadi inti dari penilaian guru terhadap peserta didiknya, orang tua terhadap anak, atau orang lain terhadap orang lainnya maupun individu kepada dirinya sendiri. Aspek kognitif adalah wadah akal yang didalamnya berisikan pikiran dan pengetahuan manusia. Sedangkan aspek afektif sebagai wadah emosi atau perasaan. Melalui emosi atau perasaan yang ditampakkan, maka kepribadian seseorang dapat terlihat. Aspek psikomotorik sebagai pelengkap 
bagi pikiran dan perasaan manusia sehingga seluruh anggota tubuh dapat bergerak. Dengan demikian, ketiga aspek ini sangat penting bagi manusia

Di bidang pendidikan, perwujudan dari aspek kognitif ialah pengetahuan, perwujudan aspek afektif ialah kepribadian, dan perwujudan aspek psikomotorik ialah ketrampilan. Pengetahuan, kepribadian, dan ketrampilan menjadi modal utama seseorang di dalam kehidupannya sehari-hari. Bahkan ketiga aspek atau komponen ini selalu menjadi tolok ukur di dalam ujian, lomba, pertandingan, bahkan rekrutmen pegawai. Untuk mendapatkan pengetahuan, kepribadian, serta ketrampilan yang baik, dimulai sejak masih anak-anak melalui bimbingan orang tua, guru, keluarga, masyarakat, dan pemerintah. Akan sangat mudah bila seseorang dikelilingi orangorang yang memahami pentingnya ketiga aspek ini diajarkan pada anak sedari dini. Selain itu, didukung dengan kondisi anak yang baik. Artinya, anak tidak mengalami disabilitas.

Disabilitas yang disandang anak bukanlah faktor yang menyebabkan anak menjadi tidak sukses di dalam kehidupannya. Namun, disabilitas yang disandang oleh anak memperlambat proses perkembangan pada aspek kognitif, afektif, dan psikomotoriknya sehingga kemampuan yang dimilikinya tidak setara dengan kemampuan yang seharusnya anak miliki sesuai dengan usianya.

Penyandang disabilitas atau lebih sering dikenal dengan anak berkebutuhan khusus, kaum difabel, atau penyandang cacat, memiliki kekhasan atau keunikan di dalam sisi fisiologis dan psikologis. Kekhasan atau keunikan tersebut awalnya menjadi hambatan bagi penyandang disabilitas. Hambatan yang sangat mempengaruhi kondisi psikologi. Tidak saja bagi penyandang disabilitas sendiri. Namun, juga bagi orang-orang yang berada di sekitarnya. Masing-masing memiliki kesulitan untuk berinteraksi antara satu dengan lainnya.
Menurut Undang-undang Republik Indonesia Nomor 8 tahun 2016 tentang Penyandang Disabilitas mendefinisikan penyandang disabilitas sebagai setiap orang yang mengalami keterbatasan fisik, intelektual, mental, dan/atau sensorik dalam jangka waktu lama yang dalam berinteraksi dengan lingkungan dapat mengalami hambatan dan kesulitan untuk berpartisipasi penuh dan efektif dengan warga negara lainnya berdasarkan kesamaan hak.

Ada banyak jemis penyandang disabilitas, diantaranya tuna netra, tuna wicara, tuna rungu, tua daksa, tuna grahita, tuna ganda, autis, attenttion deficit and hiperactivity disorder (ADHD), lamban belajar, kesulitan belajar spesifik, anak berbakat. Undang-undang Republik Indonesia Nomor 8 Tahun 2016 tentang Penyandang Disabilitas mengemukakan ragam penyandang disabilitas, yakni : a). Penyandang disabiitas fisik, b). Penyandang disabilitas intelektual, c). Penyandang disabilitas mental, d). Penyandang disabilitas sensorik. Keempat ragam penyandang disabilitas ini dapat dialami secara tunggal, ganda, atau multi dalam jangka waktu lama yang ditetapkan oleh tenaga medis sesuai dengan peraturan perundang-undangan.

Sebagian besar penyandang disabilitas memulai menyandang disabilitasnya sejak masih anak-anak, bahkan sudah sejak lahir. Walaupun, untuk beberapa ragam disabilitas baru diketahui saat usia diatas 2 tahun. Bahkan, saat anak memasuki usia sekolah. Oleh karena itu, banyak terapi atau intervensi diupayakan dilakukan sejak usia dini. Sebab, penanganan secara dini dapat mempercepat pertumbuhan dan perkembangan anak ke arah yang lebih baik.

Menurut laporan yang diterbitkan

The World Health Organization (Organisasi Kesehatan Dunia) dan Bank Dunia pada tahun 2011 dalam Pedoman Untuk Perusahaan memperkirakan ada sekitar satu juta orang di dunia yang lahir 
dan hidup dengan bentuk memiliki keterbatasan fisik/cacat atau bisa disebut dengan disabilitas. Dua hingga empat persen dari mereka diantaranya mengalami kesulitan dalam melakukan kegiatan sehari-hari. Bank Dunia juga memperkirakan terdapat dua puluh persen dari kaum miskin dunia merupakan penyandang disabilitas. Menurut PBB, delapan puluh persen dari penyandang disabilitas hidup di bawah garis kemiskinan. Sebagian besar dari mereka tinggal di daerah pedesaan dimana akses terhadap pelayanan pemerintah sangat terbatas. Dalam TNP2K (2012) menyatakan bahwa di Indonesia tidak kurang dari 24 juta atau sekitar sepuluh persen dari total jumlah penduduk Indonesia merupakan kaum difabel. Dan PPLS menyatakan bahwa enam puluh persennya hidup dalam kemiskinan asbsolut dengan jumlah pendapatan kurang dari USD1. 25 per hari (Ningsih, 2014).

Byrnes (dalam Harahap dan Bustanuddin, 2015), juga mengemukakan diperkirakan ada 650 juta penyandang disabilitas di dunia. $20 \%$ dari penduduk dunia termiskin adalah penyandang disabilitas, $98 \%$ dari anak-anak yang menyandang disabilitas di negara berkembang tidak mengenyam pendidikan, $30 \%$ anak-anak jalanan di dunia adalah penyandang disabilitas, dan $3 \%$ penyandang disabilitas yang dewasa adalah buta huruf.

Senada dengan Byrnes, Reckinger, Carole dan Winarmo (dalam Setyaningsih \& Gutama 2016), menyebutkan bahwa statistik dari PBB menunjukkan bahwa perkiraan 500.000 difabel, sekitar $80 \%$ diantaranya tinggal di negara berkembang. Kurang dari $10 \%$ mempunyai akses ke pendidikan, layanan kesehatan, dan peluang penghidupan, lebih dari $80 \%$ difabel menganggur, dan di negara-negara berkembang $75 \%-90 \%$ difabel hidup di bawah garis kemiskinan. Di Indonesia, perkiraan tentang jumlah penduduk difabel sekitar $0,25 \%$ hingga $10 \%$ dari total penduduk.

Saat ini di Indonesia sudah diterapkan pendidikan inklusif. Hampir semua sekolah memiliki peserta didik yang berkebutuhan khusus atau penyandang disabilitas. Hal ini disebabkan oleh keluhan-keluhan yang disampaikan oleh guru-guru di sekolah. Guru-guru mengalami kesulitan di dalam menghadapi peserta didik penyandang disabilitas. Khususnya di Kota Palangka Raya. Hasil pendataan Dinas Pendidikan, Kebudayaan, Pemuda, dan Olahraga Kota Palangka Raya tahun 2016 mengemukakan menunjukkan bahwa hampir semua sekolah memiliki peserta didik disabilitas. Apalagi Pemerintah Kota Palangka Raya telah menginstruksikan bahwa semua sekolah di Palangka Raya merupakan sekolah inklusi. Artinya, penyandang disabilitas tidak saja bersekolah di Sekolah Luar Biasa, tetapi juga dapat bersekolah di sekolah umum.

Hal ini sangat menguntungkan orang tua, di mana orang tua menginginkan anak-anaknya yang menyandang disabilitas dapat bersekolah di sekolah umum. Selain itu, sebagian orang tua juga tidak ingin mengakui bahwa anaknya adalah penyandang disabilitas. Mereka tetap mengakui bahwa anaknya sama dengan anak-anak lainnya dan tentunya yakin anak tersebut mampu mengikuti seluruh kegiatan di sekolah.

Kondisi ini berbanding terbalik dengan guru-guru di sekolah. Sebab, tidak semua guru mampu menghadapi dan membimbing anak-anak penyandang disabilitas ini dengan baik. Walaupun telah beeberapa kali mengikuti pelatihan menangani anak-anak penyandang disabilitas, tetap saja guru-guru masih mengalami kesulitan. Sebagian guru mengemukakan bahwa peserta didik penyandang disabilitas mengalami kesulitan dalam bidang akademik. Mereka mengalami kesulitan memahami pelajaran (Riadin, Misyanto, dan Usop, 2017). Riadin, dkk lebih lanjut mengemukakan 
penyebabnya ialah kondisi kejiwaan anakanak yang tidak mendukung, seperti tidak tenang, tidak fokus, tidak mau diatur atau senang berbuat sesuka hatinya. Selain itu, ada anak-anak yang lebih memilih untuk menggambar daripada mendengarkan penjelasan guru, tidak menuliskan jawaban soal dibuku, tulisan tidak rapi sehingga tidak dapat dibaca, tidak dapat membaca walaupun sudah berada di kelas tinggi, mengambil barang milik teman, atau menusuk-nusuk tubuh teman menggunakan pensil atau bolpoin.

Kondisi ini tentunya sangat mengganggu proses pembelajaran di sekolah. Selain peilaku-perilaku yang terkesan negatif, faktanya peserta didik penyandang disabilitas ini juga memiliki sisi positif, yakni memiliki kepribadian yang cukup baik. Mereka dapat mengikuti dan menaati peraturan di sekolah, seperti dapat meletakkan sepatu pada rak sepatu yang telah disediakan di depan kelas masing-masing, dapat melaksanakan piket kelas, juga mau membantu bila guru meminta tolong, serta rajin menjalankan ibadah puasa saat bulan ramadhan (Riadin, dkk, 2017).

Salah satu sekolah swasta di kota Palangka Raya di mana guru-gurunya juga mengalami permasalahan yang sama dengan rekan-rekan guru di sekolah lain ialah Sekolah Dasar Aisyiyah Palangka Raya. Di sekolah ada 5 (lima) peserta didik yang dianggap berbeda oleh guru-guru. Kelimanya mengalami hambatan yang berbeda-beda. Hambatan utama yakni hambatan pada bidang akademik. Guru, khususnya orang tua mengalami kesulitan di dalam menghadapi anak-anaknya. Sebab, menginginkan anak-anaknya dapat berprestasi di sekolah. Terutama mampu mengerjakan tugas-tugas yang diberikan di sekolah dengan baik. 2 (dua) diantaranya, diinformasikan mengalami autis ringan. Anak-anak ada yang memiliki hambatan dalam berbicara. Sebab, belum bisa mengucapkan beberapa huruf dengan jelas, seperti huruf $r$ atau huruf s. Selain itu, juga belum bisa membaca dan menulis.
Salah satu aspek penting yang membantu di dalam memahami bidang akademik ialah kemampuan kognitif. Aspek kognitif tidak bisa dilepaskan dari logika. Sebab, melalui di dalam berpikir, tentu ada alur, aturan, atau prosedur yang harus diikuti sehingga ketika pikiran tersebut diungkapkan, maka orang lain mengerti dan memahami pola pikir lawan bicaranya. Syafile (2010) mengemukakan :

"Logika berasal dari bahasa Yunani, yaitu "logikos" yang berarti "pengetahuan". Ilmu ataupun masuk akal, yaitu sesuatu yang berhubungan dengan cara berpikir. Dengan demikian, logika merupakan suatu teknik yang mementingkan segi formal ilmu pengetahuan, karena dalam logika kita harus menghormati berbagai cara, aturan, teori, dan metode agar suatu pernyataan menjadi sah".

$$
\text { Syafile }
$$

juga mengungkapkan kajian logika akan bergelut dengan kegiatan berpikir yang mengasah kemampuan intelektual mulai dari kegiatan sederhana seperti mengingat sampai pada pemecahan masalah. Hal ini disebut Bloom (dalam Syafile, 2010) dengan pembelajaran kognitif yang diurut sebagai berikut :

a. Pengetahuan atau pengenalan seperti mengingat informasi, fakta, terminologi, rumus sehingga kita akan mengidentifikasi, memilih, menyebut nama, dan membuat daftar (sebagai tingkat yang paling rendah)

b. Pemahaman seperti menjelaskan informasi / pengetahuan yang diketahui dengan kata-kata sendiri sehingga dengan demikian kita akan membedakan, menjelaskan, menyimpulkan, merankum dan memperkirakan (sebagai tingkat selanjutnya)

c. Penerapan seperti penggunaan informasi ke dalam situasi konteks yang baru sehingga kita akan dapat menghitung mengembangkan, 
menggunakan, memodifikasi, , dan menstransfer.

d. Analisis seperti membedakan komponen-komponen atau elemenelemen, suatu fakta, konsep, pendapat, asumsi, dan kesimpulan sehingga kita akan dapat membuat diagram, membedakan, memnghubungkan, menjabarkan ke dalam bagian-bagian.

e. Sintesis, sepeti mengkombinasikan bagian atau elemen ke dalam suatu ketentuan atau struktur yang lebih besar sehingga kita akan dapat membentuk, mendesain memformulasikan, dan membuat prediksi

f. Evaluasi seperti membuat penilaian dan keputusan tentang suatu ide, gagasan, penemuan dalil, metode, produk atau benda dengan menggunakan kriteria tertentu sehingga kita akan dapat membuat kritik, penilaian, dan evaluasi.

Utari (tanpa tahun), menyebutkan dalam taksonomi Bloom mengenai aspek kognitif (pengetahuan). Menurut Utari, ada 6 (enam) tingkatan pada aspek kognitif, yaitu : a). Mengingat, b). Memahami, c). Menerapkan, d). Menganalisis, e). Mengevaluasi/menilai, f). Mencipta.

Sehubungan dengan kondisi ini, penulis ingin mendalami perihal kemampuan kognitif pada peserta didik penyandang disabilitas di SD Aisyiyah Unggulan Bukit Tunggal Palangka Raya. Pertanyaan yang yang muncul berdasarkan uraian di atas adalah : bagaimana kemampuan peserta didik penyandang disabilitas pada aspek kognitif di SD Aisyiyah Unggulan Palangkaraya ?

\section{Metode Penelitian}

1. Pendekatan Penelitian

Pendekatan penelitian yang digunakan di dalam penelitian yang akan dilakukan ini adalah pendekatan kualitatif. Melalui pendekatan ini, peneliti akan dapat menggambarkan secara detail mengenai aspek kognitif yang dimiliki penyandang disabilitas
SD Aisyiyah Unggulan Bukit Tunggal Palangka Raya.

2. Subyek Penelitian

Adapun subyek penelitian ini ialah peserta didik penyandang disabilitas di SD Aisyiyah Unggulan Bukit Tunggal Palangka Raya.

3. Pengumpulan Data

Proses pengumpulan data yang akan dilakukan dengan beberapa cara, yaitu :

a. Pemeriksaan Psikologi

Pemeriksaan ini dilakukan guna mengetahui kecenderungan disabilitas yang dimiliki oleh peserta didik. Pemeriksaan psikologis diawali dengan observasi oleh psikolog pada hari senin, $05 \quad$ November 2018. Kemudian dilanjutkan tes kecerdasan, yakni tes CPM (Colour Progressive Matrices) pada 2 (dua) subyek dan tes WISC (Wechsler Intelligence Scale for Children) untuk 1 (satu) orang subyek.

b. Kuosioner

Kuosioner dibuat dengan tujuan untuk mengetahui kemampuan kognitif pada penyandang disabilitas. Kuosioner berisi mengenai pernyataan-pernyataan sederhana mengenai aktivitas anak sehari-hari baik di sekolah maupun di rumah. Ada 7 (tujuh) aktivitas utama, yakni : makan, minum, berpakaian, bermain, buang air besar/kecil, berkomunikasi, belajar dan kegiatan sehari-hari. Kuosioner ini terdiri atas, terdiri atas : 66 pernyataan.

Acuan pembuatan kuosioner berdasarkan buku yang ditulis oleh Syafile (2010). dan Utari mengenai Taksonomi Bloom yang menungkapkan ada 3 (tiga) ranah di dalam pembelajaran, yakni : ranah kognitif, ranah afektif, dan ranah psikomotorik. Syafile (2010), mengungkapkan bahwa logika 
disebut juga dengan pembelajaran kognitif.

Sementara itu, menurut Utari dalam tulisannya mengenai taksonomi Bloom, bahwa ranah kognitif (pengetahuan) terdiri atas : pengetahuan, pemahaman, penerapan, analisa, sintesa, dan evaluasi. Ranah afektif (sikap) terdiri atas : penerimaan, responsif, nilai yang dianut/nilai diri, organisasi dan karakterisasi. Sedangkan ranah psikomotorik (ketrampilan), terdiri atas : persepsi, kesiapan, reaksi yang diarahkan, reaksi yang kompleks, adaptasi, dan kreativitas.

c. Wawancara

Wawancara
$\begin{aligned} & \text { dengan orang thakukan } \\ & \text { maupun }\end{aligned}$
pendamping dari penyandang
disabilitas.

d. Dokumentasi

Untuk melengkapi data yang diperlukan, ada beberapa dokumen yang akan ditelaah. Dokumen-dokumen tersebut seperti : foto, video, hasil rekaman, dan hasil karya penyandang disabilitas.

4. Analisis Data

Analisis data yang digunakan adalah analisis deskriptif. Dengan demikian, peneliti dapat menggambarkan secara detail mengenai karakteristik kognitif penyandang disabilitas.

\section{Hasil Penelitian}

\section{Pemeriksaan Psikologis}

Informasi yang didapatkan penulis pada hari sabtu, 03 November 2018, bahwa di SD Aisyiyah Unggulan Bukit Tunggal Palangka Raya, ada 2 (dua) orang peserta didik yang mengalami autis, yakni peserta didik dengan inisial M.A. dan F.N.R. Selain itu, pihak sekolah juga mengemukakan bahwa ada 2 (dua) peserta didik lainnya yang mengalami hambatan di dalam belajar serta masalah dalam berbicara. Dua peserta didik tersebut berinisial D.V. dan M.R.I. Untuk mengecek kebenarannya dilakukanlah observasi oleh psikolog pada hari senin, 05 November 2018. Saat dilakukan observasi, D.V. tidak masuk sekolah karena sakit. Pihak sekolah juga mengajukan 1 (satu) orang peserta didik lainnya yang berinisial A.R.S. untuk diobservasi. Dengan demikian, ada 4 (empat) orang peserta didik yang mengikuti observasi psikologis. Hasil; observasi tersebut tampak pada tabel 1 berikut ini :

\section{Tabel 1}

Hasil Observasi Psikologis

\begin{tabular}{|c|c|c|c|}
\hline No & Nama & Kelas & Hasil Observasi \\
\hline 1 & M.A. & II & $\begin{array}{c}\text { Mengarah pada } \\
\text { gejala diagnosa } \\
\text { Intelectual } \\
\text { Disability }\end{array}$ \\
\hline 2 & F.N.R. & II & $\begin{array}{c}\text { Mengarah pada } \\
\text { beberapa dugaan } \\
\text { diagnosa seperti : } \\
\text { Pervasive } \\
\text { Developmental } \\
\text { Disorder Not } \\
\text { Otherwise } \\
\text { Specified (PDD } \\
\text { NOS), Intelectual } \\
\text { Disability, } \\
\text { Communication } \\
\text { Disability }\end{array}$ \\
\hline 3 & A.R.S. & II & $\begin{array}{c}\text { Mengarah pada } \\
\text { beberapa dugaan } \\
\text { diagnosa seperti : } \\
\text { Intelectual } \\
\text { Disability, } \\
\end{array}$ \\
& M.R.I. & V & $\begin{array}{c}\text { Specific Learning } \\
\text { Disorder } \\
\text { Mengarah pada } \\
\text { diagnosa : Speech } \\
\text { Sound Disorder }\end{array}$ \\
\hline
\end{tabular}


Kondisi tersebut di atas mengacu pada beberapa gejala, yakni :

a. M.A, mengalami gejala seperti :

1. Memiliki riwayat terlambat berjalan (usia 16 bulan) dan bicara (dua tahun hanya mengucapkan "mama".

2. Mampu menghafal surat-surat pendek yang diperdengarkan setiap hari.

3. Mampu bermain dan bersepeda.

4. Mampu berkomunikasi dengan lingkungannya.

5. Kemampuan skolastik (sekolah) masih setara anak PAUD.

6. Rentang perhatian rendah dan konsentrasi lemah.

b. F.N.R., memiliki gejala seperti :

1. Adanya kekakuan (restriction), misalnya saat sabuk tertinggal harus pulang ke rumah untuk menngambilnya.

2. Menunjukkan kemandirian yang baik, sudah mampu melakukan sebagian besar aktivitas sehari-hari tanpa banyak bantuan.

3. Mampu bermain.

4. Mampu merespon saat ditanya.

5. Tidak menunjukkan perilaku repetitif.

6. Berbicara dengan cepat sehingga kata-kata sulit dipahami.

7. Pembelajaran di sekolah lemah, masih kesulitan mengenal beberapa huruf dan baru mengenali angka 110.

c. A.R.S., memiliki gejala seperti :

1. Riwayat lahir 1,9 kilogram tanpa penanganan khusus, meski demikian riwayat perkembangan jalan dan bicara tidak menunjukkan ketertinggalan.

2. Saat bicara kurang nyambung dan lebih banyak diam.

3. Mampu bermain dan berinteraksi dengan teman sebaya.

4. Kemampuan skolastik (sekolah) rendah. Hingga saat ini belum mampu membaca dan hanya mengenal sebagian huruf.

5. Sering lupa saat diajarkan sesuatu yang berkaitan dengan pembelajaran teoritis, namun cukup mampu menyerap pembelajaran praktikal.

6. Kesulitan memahami instruksi sehingga melakukan kesalahan dalam menyelesaikan tugas yang diberikan padanya.

d. M.R.I., memiliki gejala seperti :

1. Mampu merespon lingkungannya dengan sesuai.

2. Pemalu dan kurang luwes dalam bergaul.

3. Pengucapan saat bicara kurang jelas/cadel.

4. Paham instruksi yang diberikan dan mau mengikuti aturan.

5. Mampu mengikuti pelajaran meski prestasi belajar tidak menonjol.

6. Memiliki pengalaman dirundung pada kelas 1-3 SD.

Melalui dugaan diagnosa ini, perlu dilakukan pemeriksaan lebih lanjut, yakni tes kecerdasan. Tes kecerdasan selanjutnya hanya diikuti oleh M.A, F.N.R, dan A.R.S. M.R.I. tidak mengikuti tes, sebab tidak memberikan konfirmasi kepada penulis saat diminta kesediaannya untuk mengisi kuosioner. Adapun hasil tes kecerdasan pada tabel 3 sebagai berikut : 
Tabel 2

Hasil Tes Kecerdasan

\begin{tabular}{|c|c|c|c|c|}
\hline No & Nama & $\begin{array}{c}\text { Jenis } \\
\text { Tes } \\
\text { yang } \\
\text { Diikuti }\end{array}$ & $\begin{array}{c}\text { Hasil/Kategori } \\
\text { Kecerdasan }\end{array}$ & $\begin{array}{l}\text { Diagnosa } \\
\text { hambatan }\end{array}$ \\
\hline 1 & M.A. & $\mathrm{CPM}$ & $\begin{array}{c}\text { Total Skor = } \\
\text { Berada pada } \\
\text { Golongan V } \\
\text { dengan } \\
\text { presentil di } \\
\text { bawah } 5 \%\end{array}$ & $\begin{array}{c}\text { Intelectu } \\
\text { al } \\
\text { Defectiv } \\
\text { e } \\
\text { (Tuna } \\
\text { Grahita) }\end{array}$ \\
\hline 2 & F.N.R. & CPM & $\begin{array}{c}\text { Total Skor = } \\
23 \\
\text { Berada pada } \\
\text { Golongan II } \\
\text { dengan } \\
\text { persentil }>75 \\
\%-<95 \%\end{array}$ & $\begin{array}{c}\text { Di Atas } \\
\text { Rata- } \\
\text { Rata }\end{array}$ \\
\hline 3 & A.R.S. & $\begin{array}{l}\text { WIS } \\
\text { C } 3\end{array}$ & $\begin{array}{c}\text { IQ Verbal = } \\
66 \\
\text { IQ } \\
\text { Performance } \\
=90 \\
\text { IQ Total }=75\end{array}$ & $\begin{array}{c}\text { Borderli } \\
\text { ne / } \\
\text { Ambang } \\
\text { Batas } \\
\text { (Lamba } \\
\mathrm{n} \\
\text { Belajar) }\end{array}$ \\
\hline
\end{tabular}

Tabel 2 menunjukkan perbedaan tingkat kecerdasan yang dimiliki masingmasing anak. M.A. dan A.R.S. memiliki tingkat kecerdasan yang lebih rendah daripada F.N.R. Sedangkan, hasil tes menunjukkan bahwa tingkat ecerdasan M.A. berada di bawah A.R.S. Adapun perbedaan jenis tes antara A.R.S. dengan M.A. dan F.N.R. dikarenakan pada hasil observasi A.R.S. menyebutkan bahwa A.R.S memiliki berat badan lahir rendah, saat berbicara kurang nyambung dan lebih banyak diam. Walaupun demikian, ketiganya memiliki kekurangan dalam proses pembelajaran, yakni lamban di dalam menerima pelajaran.

\section{Hasil Kuosioner}

Uraian di bawah ini menggambarkan kemampuan kognitif yang dimiliki oleh subyek penelitian.
M.A. mampu : 1). Menyampaikan rasa lapar, 2). Menyatakan keinginan untuk makan 3). Mampu mengomentari makanan yang disajikan/dimakan (enak/tidak enak, mau dimakan/tidak mau dimakan), 4). Menyampaikan rasa haus, 5). Menyatakan keinginan untuk minum, 6). Menyatakan keinginan tentang jenis minuman yang ingin diminum, 7). Mengomentari minuman yang diminum (enak/tidak enak, suka/tidak suka dengan minuman yang diminum), 8). Menyampaikan pendapat mengenai pakaian yang ingin dipakai atau pendapat tentang pakaian yang sedang dipakai, 9). Menyatakan pendapat/bercerita mengenai mainan yang ingin atau sedang dimainkan, 10). Menyatakan keinginan untuk buang air kecil/besar, 11). Membaca do'a sebelum belajar, 12). Membaca do'a setelah belajar, 13). Menjodohkan antar gambar/kata, 14). Menggambarkan dengan kata-kata hal/peristiwa yang sudah dipelajari, 15). Menggambarkan dengan kata-kata (menceritakan) kegiatan/pengalaman yang baru saja dialami, 16). Membedakan antara yang besar, tebal, panjang,, dengan yang kecil, tipis, pendek, 17). Menjelaskan keinginan, 18). Menghitung, 19). Membaca angka/lambing, 20). Melengkapi gambar/kata, 21). Menemukan peralatan/perlengkapan yang diminta untuk diambilkan, 22). Menghubungkan antar kata/kalimat/benda/gambar, 23). Menyusun kembali/merapikan perlengkapan belajar yang berantakan, 24). Menyusun kembali/merapikan mainan setelah selesai bermain, 25). Membuktikan/menunjukkan sesuatu yang dianggap menarik, 26). Mampu memisahkan benda-benda sesuai dengan fungsinya (dengan bantuan).

M.A. tidak mampu : 1). Mengetahui jenis seragam yang dipakai sesuai dengan jadwal harian, 2). Berdo'a saat masuk dan keluar kamar kecil, 3). Mengingat pelajaran yang diajarkan dengan mudah, 4). Menyebutkan kata/kalimat/simbol/lambang/dari materi 
yang diajarkan, 5). Menggambarkan peristiwa/pengalaman yang baru atau pernah dialami dan berkesan melalui gambar di buku gambar/kertas, 6). Membuat daftar atau menyusun benda/ kata sesuai dengan kategori ynang tepat, 7). Membedakan antara yang baik dan yang buruk, 8). Membedakan benar atau salah, 9). Membedakan indah/bagus atau tidak indah/tidak bagus, 10). Membuat kesimpulan dari materi pelajaran yang dibaca, 11). Membuat kesimpulan dari hasil pembicaraan/diskusi, 12). Merangkum materi sesuai arahan, 13). Memodifikasi, 14). Menggarisbawahi kata/kalimat, 15). Membuat rangka saat bermain, 16). Membuat rangka saat belajar, 17). Membaca huruf/kata/kalimat, 18). Membandingkan huruf/angka/benda sesuai dengan materi pembelajaran, 19). Mendemonstrasikan suatu hal sesuai arahan, 20). Menghubungkan suatu peristiwa dengan keadaan diri atau lingkungan di sekitarnya, 21). Mengarang/menulis cerita / menulis puisi / pantun, 22). Menyusun kata/kalimat secara tepat, 230. Menyusun angka sesuai urutan, 24). Menyusun benda/mainan sesuai fungsinya, 25). Menunjukkan sesuatu (kata/kalimat/benda/lambang) sesuai perintah, 26). Bercerita di depan kelas mengenai pengalaman, 27). Bercerita tentang pengalaman/suatu peristiwa pada guru, orang tua, saudara, teman, 28). Menterjemahkan / memahami perkataan atau tindakan orang lain, 29). Dapat mengambil keputusan atas ajakan/permintaan (guru, teman, orang tua, saudara, maupun orang lain). 30). Mampu memisahkan benda-benda sesuai dengan fungsinya (tanpa bantuan 31). Mengungkapkan persetujuan dengan katakata, 32). Mengungkapkan persetujuan dengan symbol/bagian tubuh.

F.N.R mampu : 1). Menyampaikan rasa lapar, 2). Menyatakan keinginan untuk makan, 3). Mampu mengomentari makanan yang disajikan/dimakan (enak/tidak enak, mau dimakan/tidak mau dimakan), 4). Menyampaikan rasa haus, 5). Menyatakan keinginan untuk minum, 6). Mengomentari minumam yang diminum (enak/tidak enak, suka/tidak suka dengan minuman yang diminum), 7).Mengetahui jenis seragam yang dipakai sesuai dengan jadwal harian, 8). Menyampaikan pendapat mengenai pakaian yang ingin dipakai atau pendapat tentang pakaian yang sedang dipakai, 9). Menyatakan pendapat/bercerita mengebnai mainan yang ingin atau sedang dimainkan, 10). Menyatakan keinginan untuk buang air kecil/besar, 11). Menyatakan keinginan / pendapat, 12). Menyatakan keinginan/ pendapat dengan kalimat yang tepat, 13). Membaca do'a sebelum belajar, 14). Menggambarkan dengan kata-kata hal/peristiwa yang sudah dipelajari, 15). Menggambarkan dengan kata-kata (menmceritakan kegiatan/pengalaman yang baru saja dialami), 16). Menggambarkan peristiwa/pengalaman yang baru atau pernah dialami dan berkesan melalui gambar di buku gambar / kertas, 17). Membuat daftar atau menyusun benda sesuyai dengan kategori yang tepat, 18). Membedakan antara yang baik dan buru, 19). Membedakan benar atau salah, 20). Membedakan indah/bagus, tidak indah/tidak bagus, 21). Menjelaskan keinginan, 22). Menghitung dengan bimbingan, 23). Memodifikasi, 24). Membuat rangka saat bermain, 25). Membaca angka/lambing, 26). Membaca huruf/kata/kalimat, 27). Melengkapi gambar, 28). Menemukan gambar yang hilang, 29). Menemukan peralatan/perlengkapan yang diminta untuk diambilkan, 30) Membandingkan benda saat diminta untuk membandingkan, 31). Menghubungkan suatu peristiwa dengan keadaan diri atau lingkungan di sekitarnya, 32). Menyusun angka sesuai urutan, 33). Menyusun benda/mainan sesuai fungsinya, 34). Menunjukkan sesuatu (kata/kalimat/benda/lambang) sesuai perintah, 35). Menyusun kembali/merapikan perlengkapan belajar yang berantakan, 36). Menyusun 
kembali/merapikan mainan setelah selesai bermain, 37). Bercerita tentang pengalaman / suatu peristiwa pada guru, orang tua, saudara, teman, 38). Menterjemahkan/memahami perkataan atau tindakan orang lain, 39). Membuktikan/menunjukkan sesuatu yang dianggap menarik, 40). Dapat mengambil keputusan atas ajakan/permintaan (guru, teman, orang tua, saudara, maupun orang lain), 41). Mampu memisahkan bendabenda sesuai dengan fungsinya (dengan bantuan), 42). Mampu menisahkan bendabenda sesuai fungsinya (tanpa bantuan), 43). Mengungkapkan poersetujuan dengan kata-kata, 44). Mengungkapkan persetujuan dengan simbol/bagian tubuh.

F.N.R. tidak mampu : 1). Berdo'a saat masuk dan keluar dari kamar kecil 1). Mengingat pelajaran yang diajarkan dengan mudah, 3). Menyebutkan kata/kalimat/symbol/lambang dari materi yang diajarkan, 4). Menjodohkan antar gambar/kata, 5). Membuat daftar atau menyusun kata sesuai dengan kategori yang tepat, 6). Membuat kesimpulan dari materi pelajaran yang dibaca, 7). Membuat kesimpulan dari hasil pembicaraan/diskusi, 8). Menggaris bawahi kata/kalimat, 8). Membuat rangka saat belajar , 10). Melengkapi kata, 11). Menemukan kata yang hilang, 12). Membandingkan huruf/angka/benda sesuai dengan materi pelajaran, 13). Mendemonstrasika suatu hal sesuai arahan, 14). Menghubungkan antar kata/kalimat/benda/gambar, 15). Mengarang/menulis cerita/menulis puisi/pantun, 16). Menyusun kata/kalimat dengan tepat, 17). Bercerita di depan kelas mengenai pengalaman.

A.R.S mampu : 1). Menyampaikan rasa lapar, 2). Menyatakan keinginan untuk makan, 3). Mampu mengomentari makanan yang disajikan /dimakan (enak/tidak enak, mau dimakan/tidak mau dimakan), 4). Menyampaikan rasa haus, 5). Menyatakan keinginan untuk minum, 6)/ Menyatakan keinginan tentang jenis minuman yang ingin diminum, 7). Mengomentari minuman yang diminum (enak/tidak enak, suka/tidak suka dengan minuman yang diminum), 8). Menyampaikan pendapat mengenai pakaian yang ingin dipakai atau pendapat tentang pakaian yang sedang dipakai, 9). Menyatakan pendapat/bercerita mengenai mainan yang ingin atau sedang dimainkan, 10). Menyatakan keinginan untuk buang air kecil/besar, 11). Menyatakan keinginan/menyampaikan pendapat, 12). Menemukan peralatan/perlengkapan/yang diminta untuk diambilkan, 13). Membuktikan/menunjukkan sesuatu yang dianggap menarik, 14). Mampu memisahkan benda-benda sesuai dengan fungsnya (dengan bantuan)

A.R.S tidak mampu : 1). Mengetahui jenis seragam yang dipakai sewsuai dengan jadwal harian, 2). Berdo'a saat masuk dan keluar kamar kecil, 3). Menyatakan keinginan/pendapat dengan kalimat yang tepat, 4). Membaca do'a sebelum dan sesudah belajar, 5). Mengingat pelajaran yang diajarkan denganm mudah, 6). Menyebutkan kata/kalimat/symbol//lambang dari materi yang diajarkan, 7). Menjodohkan antar gambar/kata, 8). Menggambarkan dengan kata-kata hal/peristiwa yang sudah dipelajari, 9). Menggambarkan dengan kata-kata (menceritakan) kegiatan/pengalaman yang baru saja dialami, 10). Menggambarkan peristiwa/pengalaman yang baru atau pernah dialami dan berkesan melalui gambar di buku gambar/kertas, 11). Membuat daftar atau menyusun benda/kata sesuai dengan kategori yang tepat, 12). Membedakan antara yang baik dan buruk, 13). Membedakan benar atau salah, 14). Membedakan indah/bagus atau tidak indah/tidak bagus, 15). Membedakan antara yang besar, tebal, panjang dengan yang kecil, tipis, pendek, 16). Menjelaskan keinginan, 17). Membuat kesimpulan dari materi pelajaran yang dibaca, 18). Membuat kesimpulan dari hasil pembicaraan/diskusi, 19). Merangkum 
materi sesuai dengan arahan, 20). Menghitung, 21). Memodifikasi, 22). Menggarisbawahi kata/kalimat, 23). Membuat rangka saat bermain, 24). Membuat rangka saat belajar, 25). Membaca angka/lambing, 26) Membaca huruf/kata/kalimat, 27). Melengkapi gambar/kata, 28). Menemukan kata/gambar yang hilang, 29). Membandingkan huruf/angka/benda sesuai dengan materi pelajaran, 30). Membandingkan benda saat diminta untuk dibandingkan, 31). Mendemonstrasikan suatu hal sesuai arahan, 32). Menghubungkan antar kata/kalimat/benda/gambar, $\quad 330$. Menghubungkan suatu peristiwa dengan keadaan diri atau lingkungan di sekitarnya, 34). Mengarang/menulis cerita/menulis puisi/pantun, 35). Menyusun kata/kalimat secara tepat, 37). Menyusun angka sesuai urutan, 37). Menyusun benda/mainan sesuai fungsinya, 38). Menunjukkan sesuatu (kata/kalimat/benda/lambang) sesuai perintah, 39). Menyusun kembali/merapikan perlengkapan belajar yang berantakan, 40). Menyusun/merapikan kembali mainan setelah selesai bermain, 41). Bercerita di depan kelas mengenai pengalaman, 42). Bercerita tentang pengalaman/suatu peristiwa pada guru, orang tua, saudara, teman, 43). Menterjemahkan/memahami perkataan/tindakan orang lain, 44). Dapat mengambil keputusan atas ajakan/permintaan (guru, teman, orang tu, saudara maupun orang lain), 45). Mampu memisahkan benda-benda sesuai dengan fungsinya (tanpa bantuan), 46). Mengungkapkan persetujuan dengan katakata, 47). Mengungkapkan persetujuan dengan simbol/bagian tubuh)

\section{Hasil Wawancara}

a. M.A.

1. M.A. merupakan anak pertama dari 2 (dua) bersaudara

2. M.A. mempunyai adik yang masih berusia balita
3. Pada usia balita, M.A. pernah dibawa orang tuanya ke Rumah Sakit Doris Sylvanus karena belum bisa bicara diusia menginjak 3 tahun

4. Hasil pemeriksaan, M.A. divonis mengalami autis ringan dan menjalani terapi

5. Menginjak kelas 2 SD ini, M.A, masih belum bisa menulis sehingga pembelajaran M.A antara lain : mewarnai gambar, mengenal huruf dan angka, menebalkan huruf dan angka, meniru huruf dan kata, menggambarkan benda sebanyak angka yang tertera pada buku.

6. M.A. masih berbicara dengan cadel, tetapi arah perkataan/kalimat dapat dipahami.

7. Mampu melakukan kegiatan/aktivitas sehari-hari.

8. M.A. ingin makan bila makanan sesuai dengan seleranya

9. Dapat memakai pakaian sendiri, khususnya kaos. M.A. belum bisa memakai pakaian berkancing serta memakai sabuk.

10. M.A. mengingat pakaian seragam yang dikenakan pada hari rabu, yakni memakai seragam batik. Sebab, masih bingung atau belum hafal di luar kepala nama-nama hari.

11. M.A. sudah hafal Al Qur'an Surat Al-Fatihah, Surat Al-Ikhlas, dan Surat An-Nas.

12. Selain hafal do'a sebelum makan, M.A. juga hafal do'a sebelum tidur

13. Ada rasa malu yang dimiliki, seperti saat menggunakan celana bolong, harus diganti karena merasa malu, ingin membeli kembang api.

14. Ketika meminta sesuatu kepada orang tua, namun masih belum dapat dipenuhi orang tua, M.A. dapat menerima lasan yang dikemukakan orang tuanya.

Misalnya, saat M.A. minta handphone (HP) yang lebih besar 
dari yang sudah ada, mainan motor baru, mainan traktor, ingin perbaiki sepeda yang rusak.

Orang tua tidak dapat memenuhi dan mengatakan "ya, nanti tunggu ada uangnya", atau "iya, nantilah kalau ayah punya uang".

15. Saat megajak adik untuk bermain, kalimat ajakan yang diucapkan : "ayo dek, main sama kakak".

16. Dapat bermain puzzle, hanya saja belum dapat membentuk suatu bangunan. Bentuk yang disusun adalah menyusun balok-balok puzzle sampai tinggi.

17. Mau membantu saat diminta tolong untuk membantu, seperti mengupas bawang, membeli garam.

18. Jika diminta tolong ibu membeli keperluan dapur di warung, harus membawa catatan bila barang yang dibeli lebih dari satu. Bila hanya satu, maka tidak menggunakan catatan.

19. Hubungan dengan teman-teman masih belum berjalan lancar, sebab M.A. sering dijahili teman, seperti dilempar pasir, disuruh mencium sepatu, dikasih ulat. Sementara M.A. tidak dapat melawan.

20. M.A. berbicara masih cadel, khususnya saat membunyikan huruf "s" dan huruf "r".

b. F.N.R.

1. Anak kedua dari 2 (dua) bersaudara

2. F.N.R. sudah bisa membaca saat usia 2 tahun

3. Berbicara masih kurang jelas

4. Mampu mengingat dengan baik tempat benda-benda, khususnya mainan yang dimiliki. Saat mainan bergeser/berpindah tempat atau tidak ada di tempatnya, F.N.R. mengetahuinya

5. Memiliki inisiatif yang baik. Misal, saat ibu merawat tanaman di pot, F.N.R. berinisiatif sendiri mengembalikan pot tersebut pada tempatnya.
6. Beberapa hal sederhana harus dilakukan, seperti saat tertinggal sabuk/ikat pinggang saat sudah sampai di sekolah, tetap harus pakai sabuk sehingga pulang kembali ke rumah. Contoh lain, saat akan menaruh sepatu di rak sepatu di sekolah, harus berjalan dengan lutut karena tidak mau loantai kotor.

7. Kondisi perekonomian orang tua berada di kelas menengah ke bawah tetapi masih mampu memenuhi kebutuhan pendidikan dan media belajar anak (F.N.R).

\section{c. A.R.S}

1. Anak pertama dari 2 (dua) bersaudara.

2. Memakai pakaian yang ada krahnya kadang-kadang masih memerlukan bantuan.

3. Belum mampu mengingat nama hari di luar kepala sehingga belum dapat mengingat jenis seragam yang dikenakan sehari-hari.

4. Belum lancar dalam membaca do'a, masih terputus-putus dan dipikirkan.

5. Sangat pendiam. Jarang bicara. Lebih banyak menggunakan bahasa tubuh, seperti mengangguk dan menggeleng.

6. Kurang bisa berkreasi dengan mainan sebab, sangat sedikit sekali mainan yang dimiliki.

7. Belum bisa membaca. Ulangan didiktekan guru. A.R.S. hanya memilih jawaban yang didiktekan guru.

8. Kondisi perekonomian orang tua berada di kelas menengah ke bawah dan kurang dapat memenuhi kebutuhan pendidikan anak (A.R.S.) sebab rumah sebagai tempat tinggal adalah rumah yang ditempati tanpa ada pembiayaan sewa dikarenakan ketidakmampuan orang tua membayar biaya sewa. Selain itu, pekerjaan yang dilakukan oleh ayah A.R.S. sebagai 
pemelihara hewan ternak (kambing, ayam) milik orang lain.

\section{Pembahasan}

Berdasarkan hasil pemeriksaan psikologis, ketiga subyek (M.A., F.N.R, dan A.R.S.) memiliki kesamaan, yaitu sama-sama diduga mengalami masalah didalam belajar. Saat psikolog melakukan observasi, ketiganya diduga mengalami masalah dengan kecerdasan yang diistilahkan dengan intellectual disability (disabilitas intelektual), yakni terganggunya fungsi pikir karena tingkat kecerdasan di bawah rata-rata, antara lain : lamban belajar, tuna grahita, dan down syndrome (Pawestri, 2017). Senada dengan Pawestri, Retnaningsih \& Hidayat (2012), mengemukakan bahwa anak dengan disabilitas intelektual merupakan anak yang memiliki hambatan dalam kognitif, afektif, psikomotorik. Secara kognitif, memiliki fungsi intelektual di bawah ratarata (Albrecht, Seelman, \& Bury (dalam Retnaningsih \& Rahmat, 2012).

Hasil tes inteligensi, menyatakan bahwa M.A. mengalami intellectual defective atau intellectual disability (tuna grahita). Sedangkan F.N.R. memiliki kecerdasan di atas rata-rata dan kecerdasan A.R.S berada diambang batas (Borderline). Walaupun F.N.R. memiliki kecerdasan di atas rata-rata, namun F.N.R. juga mengalami gangguan perkembangan pervasif yang tidak terspesifikasi (Pervasive Development Disorder Not Otherwise Specified / PDD NOS). Kondisi ini mengakibatkan ketiganya mengalami kesulitan di dalam kegiatan pembelajaran, baik di sekolah maupun di rumah. Berikut pembahasan mengenai subyek penelitian.

\section{M.A.}

M.A. saat ini berusia 8 (delapan) tahun dan berada di kelas 2 (dua) sekolah dasar. M.A. berasal dari keluarga dengan tingkat perekonomian berada pada ekonomi kelas menengah ke bawah dengan hanya ayah yang bekerja sebagai tukang bangunan. Sedangkan ibu M.A. tidak bekerja. Ibu M.A. hanya membantu membuatkan masakan untuk guru-guru di sekolah.M.A mempunyai seorang adik laki-laki dan belum bersekolah. Berdasarkan hasil tes inteligensi, yaitu tes CPM (Colour Progressive Matrics). Total skor yang diperoleh adalah dari 36 soal dengan presentil di bawah 5 (lima). Hal ini menandakan bahwa kecerdasan yang dimiliki M.A. sangat rendah. Berdasarkan hasil tes ini, psikolog menyatakan bahwa M.A. mengalami intelectual defective atau intelectual disability (hambatan disabilitas), yaitu : terganggunya fungsi pikir karena tingkat kecerdasan di bawah rata-rata, antara lain : lamban belajar, disabilitas grahita, dan down syndrome (Pawestri, 2017).

Di dalam DSM-5 yang diterbitkan oleh American Psychriatic Association (2013), menyebutkan bahwa intelectual disability (hambatan intelektual), yaitu suatu gangguan pada masa perkembangan yang terdiri atas kekurangan dalam fungsi intelektual dan fungsi adaptif baik secara konsep, sosial, dan domain praktis. Di Indonesia, istilah intelectual disability diartikan dengan tuna grahita.

Selain itu, juga memiliki fokus atau perhatian yang kurang dan menjawab pertanyaan atau perkataan tanpa memikirkan terlebih dahulu maksud sebenarnya. M.A. juga lebih sibuk dengan dirinya sendiri sehingga kurang memperhatikan saat orang lain berbicara. Pada kuosioner yang diisi oleh orang tua (ibu) M.A., M.A. tampak mengalami kesulitan di dalam berinteraksi dengan orang lain. Misalnya untuk menjawab atau merespon pembicaraan dengan segera, memperhatikan guru di kelas saat pelajaran berlangsung, memperhatikan orang lain saat berbicara, mau mendengarkan orang lain saat berbicara mentaati peraturan di sekolah, menyesuaikan diri dengan guru, temanteman, maupun pada lingkungan baru.

Berkenaan dengan sikap dan tutur kata, untuk anak seusia M.A. dengan hambatan yang dimilikinya, M.A. cukup 
sopan. Terbukti, saat berbicara M.A. mempunyai rasa ingin tahu cukup besar dengan menanyakan keperluan penulis datang ke rumah dan mau diajak mengobrol dengan penulis. Pertanyaannya sangat sederhana, terdiri atas 2-4 kata saja. Tetapi, cukup jelas, seperti : "mau apa ke sini ?”, "untuk apa?".

Penulis juga balik bertanya. Saat menjawab, M.A. tampak berpikir tentang hal yang dibicarakan lawan bicaranya. Tampak bingung, sehingga ibu menjelaskan. Ketika, penulis bertanya mengenai kemampuan M.A. mengenal angka. Ibu M.A. memintanya untuk membuka buku pelajaran dan menunjukkan angka-angka yang tertera di buku. Berkisar dari angka 1 sampai dengan angka 10. M.A. M.A. belum mampu mengingat semuanya dan ada beberapa angka yang salah saat ditunjuk oleh M.A.

\section{F.N.R.}

F.N.R. memiliki seorang kakak perempuan yang senang bermain dengan F.N.R. Keduanya, anak-anak yang ceria. F.N.R. sangat aktif walaupun bicaranya masih belum jelas. Penyebutan huruf-huruf yang keluar dari mulut F.N.R. tampak seperti penyebutan anak balita yang baru belajar bicara. Hal ini menjadi perhatian orang tua, khususnya ibu dari F.N.R

Saat ini, F.N.R. berusia 8 (delapan) tahun dan duduk di bangku kelas 2 (dua) sekolah dasar. Hasil tes Colour Progressive Matrics (CPM) yang diikuti pada tanggal 06 Desember 2018, Waktu yang diperlukan F.N.R. untuk mengikuti tes hanya 10 menit. Lebih cepat dari M.A. yang mampu menyelesaikan tes selama 25 menit. Total skor yang diperoleh adalah 23 dengan rentang presentil berada pada $>75 \%$ - $<95 \%$ dan berada pada golongan II. Hal ini menunjukkan bahwa tingkat kecerdasan F.N.R. berada di atas rata-rata.

Hal ini senada dengan hasil kuosioner yang diisi oleh ibu dari F.N.R., yang mana hampir seluruh kegiatan sederhana terkait kemampuan mengurus diri sendiri seperti kegiatan makan, minum, berpakaian, berkomunikasi, buang air kecil/besar, bermain, dan juga pada kegiatan belajar. F.N.R. memiliki ingatan yang kuat mengenai letak barang atau mainannya. Ia mengetahui bila ada mainannnya yang berpindah tempat atau tidak ada pada tempatnya. F.N.R. juga seorang anak yang memiliki inisiatif cukup baik. Ia mau membantu ibunya tanpa disuruh. Misalnya, saat ibu membersihkan halaman rumah dan potpot tanaman dipindahkan, F.N.R. tanpa disuruh, berinisiatif mengembalikan pot tanaman yang sudah selesai dibersihkan pada tempatnya. F.N.R juga aktif dan cepat akrab dengan orang yang baru dikenal. Tanpa sungkan, ia menyapa dan bersalaman dengan orang yang belum lama dikenalnya.

Kelemahan F.N.R. terletak pada kemampuan untuk mengingat pelajaran. Hal ini menjadi alasan pada hasil pemeriksaan psikologis oleh psikolog mengenai kemampuan menerima pelajaran di sekolah yang lemah yaitu : kesulitan mengenal beberapa huruf dan baru mengenali angka 1-10.

Berdasarkan hasil pemeriksaan psikologis, ada dugaan dari psikolog bahwa F.N.R. juga mengalami Pervasive Developmental Disorder Not Otherwise Specified (PDD NOS). Hal ini mengacu kepada hasil diagnostik dokter saat F.N.R. masih berusia di bawah lima tahun. F.N.R. didiagnosa mengalami autis ringan dikarenakan adanya kekakuan (restriction). Kekakuan tersebut seperti saat sabuk tertinggal ketika sudah sampai di rumah, maka harus pulang mengambilnya.

Informasi yang didapatkan dari guru, F.N.R. cukup kaku pada hal-hal yang dianggap sepele oleh orang lain. Misalnya terkait dengan kepemilikan barang. F.N.R. mengetahui bahwa setiap orang (teman) memiliki alat tulis masing-masing. Tentunya saat alat tulis tersebut diperlukan, seseorang tidak harus meminjam alat tulis pada orang lain. 
Melalui peikiran ini, F.N.R. merasa terganggu bila ada temannya yang meminjam atau mengambil barang/alat tulis temannya. Ia segera berkata bahwa barang tersebut milik temannnya dan harus segera dikembalikan.

M.A. dan F.N.R. teman sekelas. Saat ini keduanya berada di kelas dua sekolah dasar M.A. memiliki karakter senang mengganggu/menjahili temannya. Ia senang meminjam alat tulis temannya. Bagi F.N.R., hal ini sangat mengganggu dan tidak disukainya, F.N.R. segera berkata : "itu buka punyamu, kembalikan !’. M.A. yang mengetahui karakter F.N.R. ini, menjadi senang menggoda temannya ini. M.A. bisa mengambil pensil teman yang berada didekatnya, kemudian memanggil F.N.R seraya melambailambaikan pensil yang telah diambilnya. F.N.R segera bereaksi dan suasana kelas pun menjadi ramai. Walaupun demikian, F.N.R. sangat senang dengan M.A., saat M.A. melakukan sesuatu yang dianggapnya salah, ia segera menegur M.A.

Di sisi lain, F.N.R. sampai hari ini belum mau ditinggal sendiri di sekolah. Oleh sebab itu, ibu F.N.R. menemani dari pagi samai pulang sekolah. Bila ada keperluan sampai harus meninggalkan F.N.R, ibu memberi tahu terlebih dahulu sebelum berangkat dan mencari alsan yang dapat diterima anaknya.

3. A.R.S.

A.R.S. adalah teman M.A. dan F.N.R. Mereka bertiga satu kelas. Saat ini, A.R.S. berusia 8 (delapan) tahun. Ia mempunyai seorang adik permpuan yang belum bersekolah. A.R.S. memiliki kepribadian yang sangat pendiam. Berbicara pada halhal yang dianggap perlu saja. Dalam berkomunikasi, A.R.S. lebih banyak merespon pembicaraan dengan anggukan atau gelengan kepala.

Hasil pemeriksaan psikologis, A.R.S. memiliki riwayat lahir $1,9 \mathrm{~kg}$ tanpa penanganan khusus. Perkembnagan A.R.S. juga tidak mengalami hambatan. A.R.S. disebutkan saat berbicara kurang nyambung dan memiliki kemampuan skolastik (sekolah) yang rendah. Dalam hasil pemeriksaan psikologis dijelaskan bahwa A.R.S. belum mampu membaca dan baru mengenal huruf. Selain itu, A.R.S. juga sering lupa dan kesulitan memahami instruksi sehingga melakukan kesalahan dalam menyelesaikan tugasnya.

Berdasarkan hasil pemeriksaan psikologis ini, A.R.S. mengikuti tes inteligensi WISC (Wechsler Intelligence Scale for Children) versi 3. Hasilnya menunjukkan bahwa IQ verbal A.R.S. adalah 66 dan IQ performance sebesar 90 dengan total IQ sebesar 75. Angka ini berada pada kategori ambang batas (borderline). Artinya, kecerdasan A.R.S. berada di bawah rata-rata atau di bawah normal. Tetapi, belum samapai pada taraf inteligensi anak tuna grahita. Tabel 4 berikut ini menunjukkan klasifikasi aspekaspek psikologis A.R.S.

Tabel 3 Aspek Kemampuan Psikologis

\begin{tabular}{|c|l|c|}
\hline No & \multicolumn{1}{|c|}{$\begin{array}{c}\text { Aspek } \\
\text { Psikologis }\end{array}$} & Kategori \\
\hline 1 & Konsentrasi Ingat & Kurang \\
\hline 2 & $\begin{array}{l}\text { Daya Ingang } \\
\text { Auditori }\end{array}$ & Baik \\
\hline 3 & $\begin{array}{l}\text { Daya Ingat } \\
\text { Visual }\end{array}$ & Sedang \\
\hline 4 & $\begin{array}{l}\text { Daya } \\
\text { Visual Motor }\end{array}$ & Rendah \\
\hline 5 & $\begin{array}{l}\text { Pengetahuan } \\
\text { Umum }\end{array}$ & Kurang \\
\hline 6 & $\begin{array}{l}\text { Penilaian sosial } \\
\text { Verbal }\end{array}$ & Kurang \\
\hline 7 & $\begin{array}{l}\text { Penalaran Non } \\
\text { Verbal }\end{array}$ & Kurang \\
\hline 9 & $\begin{array}{l}\text { Kemampuan } \\
\text { Numerik }\end{array}$ & Kurang \\
\hline 10 & Kecepatan & Sedang \\
\hline 11 & $\begin{array}{l}\text { Sikap Kerja di } \\
\text { Bawah Tekanan }\end{array}$ & Kurang \\
\hline
\end{tabular}


Dari 11 (sebelas) aspek kemampuan psikologis, daya ingat visual A.R.S. adalah yang terbaik diantara aspek-aspek kemampuan psikologis lainnya. Sementara itu aspek daya ingat visual motor dan kecepatan berada pada taraf "sedang". Aspek lainnya berada pada kategori "kurang" dan kategori "rendah" pada aspek pengetahuan umum. Hal ini menunjukkan bahwa A.R.S. lebih mudah memahami bila belajar dengan cara melihat dan praktek.

Kondisi ini sesuai dengan hasil kuosioner yang menunjukkan bahwa A.R.S. mampu mengerjakan aktivitasaktivitas sederhana yang dilakukan seharihari, seperti makan, minum, mandi, berpakaian, serta membersihkan diri. Layaknya anak-anak pada umumnya, A.R.S. memiliki rasa ingin tahu yang besar dan ingin melakukan hal yang dilakukan oleh orang dewasa. Misalnya, A.R.S. ingin makan telur. A.R.S. melakukan sebagaimana yang diketahuinya saat ingin masak telur. A.R.S. mencoba menyalakan kompor. Akan tetapi, ibu A.R.S. belum mengizinkan karena khawatir.

Kelemahan terbesar A.R.S. adalah dalam hal "mengingat". A.R.S. mengalami kesulitan mengingat materi-materi pelajaran. Bahkan, A.R.S. belum lancar membaca.A.R.S. masih belajar mengenal huruf. Di sekolah, guru memberikan tugas menyalin kata. Didukung dengan karakter A.R.S. yang pendiam dan penurut, A.R.S. selalu mengerjakan tugas-tugas dari guru. Ketika ditanya "apakah sudah paham penjelasan guru?". A.R.S mengiyakan dan mengerjakan tugas. Namun, hasilnya ternyata tidak sesuai dengan harapan guru.

Secara afektif, A.R.S. cukup beretika. Berdasarkan kuosioner yang diisi ibu A.R.S., A.R.S. mau membantu orang lain jika disuruh. Selain itu, mau berbagi dengan teman-teman, dapat mengucapkan terima kasih (jika disuruh), serta mau menerima kekalahan. Hal ini sangat didukung kepribadian A.R.S. yang pendiam. Oleh karena itu, guru sering lupa bila A.R.S. juga memerlukan bimbingan ekstra di kelas. Sebab, dianggap memiliki kemampuan yang sama degan temanteman lainnya.

Adapun pada aspek psikomotorik, A.R.S. sangat kurang kemampuan berkreasi. Hal ini didukung oleh pengetahuan umum yang rendah, di mana kemampuan mengingat sebagai kelemahannya. Faktor lain yang mendukung ialah keadaan ekonomi keluarga A.R.S. yang sangat kurang, di mana A.R.S. bersekolah tanpa harus membayar SPP. Selain itu, orang tua (ayah) bekerja bila ada orang lain yang meminta bantuan. Mainan jarang dibelikan. Hampir-hampir tidak ada mainann di rumah A.R.S.

\section{Kesimpulan Dan Saran}

Berdasarkan hasil penelitian dapat dimpulkan bahwa :

1. Subyek penelitian (M.A., F.N.R., A.R.S), mengalami hambatan dalam bidang akademik. Khususnya berkaitan dengan kemampuan mengingat. Hal ini dikarenakan hambatan intelektual yang ada pada M.A. dan A.R.S., serta Pervasive Developmental Disorder Not Otherwise (PDD NOS) yang dialami F.N.R.

2. Rendahnya kemampuan mengingat, khususnya mengingat pelajaran mengakibatkan subyek masih belajar membaca dan menulis di kelas 2 (dua) sekolah dasar.

\section{DAFTAR PUSTAKA}

American Psychiatric Association. 2013. Diagnostic and Statistical Manual of Mental Disorders. Fith Edition. DSM-5 ${ }^{\mathrm{TM}}$. Arlington : New School Library

Harahap, R.R. dan Bustanuddin. 2015. Perlindungan Hukum Terhadap penyandang disabilitas menurut Convention On The Rights Of Persons With Disabilities 
(CRPD). Jurnal Inovatif. Volume VIII, Nomor I, Pp. 17-29

Ningsih, E.R. 2014. Mainstreaming Isu Disabilitas di Masyarakat dalam Kegiatan Penelitian maupun Pengabdian pada Masyarakat di STAIN Kudus. Jurnal Penelitian, Vol. 8, No. 1, Pp. 7192

Pawestri, Aprilina. 2017. Hak Penyandang Disabilitas dalam Perspektif HAM Internasional dan HAM Nasional. Era Hukum. Vol. 2, Nomor 1, Pp. 164-182

Retnaningsih, Ira \& Hidayat, Rahmat. 2012. Representasi Sosial tentang Disabilitas Intelektual pada Kelompok Teman Sebaya. Jurnal Psikologi. Vol. 39, No. 1. Pp. 13-24

Riadin, Agung; Misyanto; Usop, D.S. 2017. Karakteristik Anak Berkebutuhan Khusus di Sekolah Dasar Negeri (Inklusif) di Palangka Raya. Anterior Jurnal. Vol 17, Issue 1, Pp. 2227

Setyaningsih, R dan Gutama, Th.A. 2016. Pengembngan Kemandirian Bagi kaum Difabel : Studi Kasus pada Peran Paguyuban Sehati dalam Upaya Pengembnagan Kemandirian bagi Kaum Difabel di Kabupaten Sukoharjo. Jurnal Sosiologi DILEMA, Vol. 31, No. 1, Pp. $42-52$

Syafile, Inu Kencana. 2010. Pengantar Filsafat. Bandung. PT. Refika Aditama

Undang-undang Republik Indonesia Nomor 8 Tahun 2016 Tentang Penyandang Disabilitas

Utari, Retno, .......... Taksonomi Bloom : Apa dan Bagaimana Menggunakannya. Widyaiswara Madya. Pusdiklat KNPK 